\title{
IX Międzynarodowe Sympozjum Liturgiczne Ars liturgica. L'arte a servizio della liturgia (Monastero di Bose, 2-4 czerwca 2011)
}

W dniach od 2 do 4 czerwca 2012 roku w Opactwie w Bose odbyło się IX Międzynarodowe Sympozjum Liturgiczne pt. Ars Liturgica. L'Arte a servizio della liturgia (Ars liturgica. Sztuka w stużbie liturgii). Organizatorem sympozjum byli: Wspólnota Bose wraz z Narodowym Urzędem dla Kościelnych Dóbr Kultury przy Konferencji Episkopatu Włoch, jak i Urzędem ds. Liturgii przy Konferencji Episkopatu Włoch. W sympozjum uczestniczyło około 200 osób (liturgiści, architekci, artyści) z wielu krajów Europy i kilkunastu ośrodków naukowych.

Po przywitaniu uczestników i odczytaniu przesłanych listów (m.in. od Ojca Świętego Benedykta XVI i patriarchy Konstantynopola Bartłomieja) przeor Wspólnoty z Bose Enzo Bianchi wprowadził uczestników w temat sympozjum. Zauważył on, że punkty Konstytucji o Liturgii świętej 122-130 nie zostały dotychczas dogłębnie przeanalizowane i często są pomijane. Stwierdził również, że sztuka pełni rolę służebną wobec liturgii, a nie stanowi jej części konstytutywnej, jak również, że nie każda sztuka religijna jest sztuką liturgiczną. Sympozjum ma pomóc znaleźć odpowiedź, czy sztuka liturgiczna właściwie opowiada o Bogu, który stwarza, uświęca, ożywia i błogosławi.

Jako pierwszy z prelegentów zabrał głos Yves-Marie Blanchard (Institut Catholique Paris), który przedstawił zagadnienie Czy sacrum istnieje w Nowym Testamencie? (Esiste il sacro nel Nuovo Testamento?). Rozpoczął on od stwierdzenia, że sacrum oznacza „rzeczywistość oddzieloną od”. W Starym Testamencie była to rzeczywistość bardzo ważna i codziennie doświadczana. Izraelita ciągle żył między sacrum a profanum, między „czystością” a „nieczystością”, między codziennymi obowiązkami a rytuałem. Jezus Chrystus przez tajemnicę wcielenia, tzn. przyjęcia ludzkiego ciała, złamał obowiązującą relację sacrum-profanum. Bóg zbliżył się do człowieka aż tak blisko, że kto widzi Chrystusa, widzi Boga. Miejscem sacrum jest Jezus Chrystus. Choć samo słowo sacrum nie występuje w Nowym Testamencie, są pewne sytuacje, które je wyrażają: sacrum nie zależy od rzeczy, ale od relacji wzajemnej człowieka złączonego z Bogiem.

Drugim prelegentem pierwszego dnia obrad był Uwe Michael Lang (Università Europea Roma), który przedstawił wykład Liturgia i język sacrum. Konfrontacja stanowisk (La liturgia e il linguaggio del sacro. Posizioni a confronto). Zauważył, że słowo „konsekracja” ma trzy znaczenia: konsekracja Syna przez Ojca, konsekracja Jezusa Chrystusa przez siebie samego (modlitwa arcykapłańska), uczestnictwo wiernego w kapłaństwie Jezusa Chrystusa (Jezusa posyła apostołów na cały świat). Autor odwołał się do definicji liturgii zawartej w konst. Sacrosanctum Concilium, enc. Mediator Dei i nauczaniu św. Tomasza z Akwinu, podkreślając, że liturgia jest święta (sacra), gdyż działa w niej sam Jezus Chrystus. „Kult w duchu i prawdzie” nie oznacza wykluczenia użycia materii w kulcie 
Boga. Zadaniem sztuki sakralnej jest wprowadzić w sakramentalność, jak również oddać w sposób widzialny akt wiary. Dziś jednak brak jest kryteriów teologicznych dla sztuki sakralnej. Ani enc. Mediator Dei, ani konst. Sacrosanctum Concilium nie mówią o relacji liturgia-sztuka i nie podają dokładnych kryteriów teologicznych. Prelegent, odwołując się często do nauki Benedykta XVI, podkreślił, że sztuka chrześcijańska musi uwzględnić inkarnację Syna Bożego i umiejętnie łączyć elementy nowe z tradycją.

Trzecim i ostatnim referentem pierwszego dnia był Thomas Sternberg (Westfälische Wilhelms Universität Münster), który przedstawił ten sam temat. Rozpoczął on od stwierdzenia, że w przestrzeni kościoła to, co jest profanum, może być dobre. Odwołał się w ten sposób do myśli J. Piepera. Sakralność pojawia się tam, gdzie panuje silentium. O sakramentalności dzieła nie decyduje wola jego autora, ale akt dedykacji. Mówiąc o sakramentalności, wyróżnił w niej wiele kategorii, np. estetyczną, symboliczną, personalną, odmienności, artystyczną. Obecnie Kościół ma problem z określeniem, co to jest sztuka sakralna czy architektura sakralna, gdyż w przeszłości dawał on co prawda kryteria dla sakralności, ale nieraz okazywały się one niewłaściwe.

Drugi dzień obrad rozpoczął się od wystąpienia Roberta F. Tafta (Pontificio Istituto Orientale Roma) na temat: Piękno które zbawi świat. Sztuka i liturgia na ortodoksyjnym Wschodzie (La bellezza che salverà in mondo. Arte e liturgia nell'Oriente ortodosso). Sam tytuł prezentacji prelegent zaczerpnął z powieści Idiota F. Dostojewskiego. Podkreślił on, że na Wschodzie „piękno” jest „sposobem wcielenia”, co wyraziło się w widzialnym obliczu Jezusa Chrystusa w świecie. W myśli ortodoksyjnej Kościół jest niebem na ziemi. Stąd ikonografia w kościele, mury, freski, mozaiki, meble, sztuka liturgiczna - wszystko to wyraża dynamikę Kościoła. Kościół nie służy tylko prywatnej modlitwie, ale jest przede wszystkim przestrzenią wejścia w komunię ze wszystkimi świętymi. Liturgia w nim to teofania Boga, ona jest najważniejsza, ona jest „teologią pierwszą”.

Następnie Giuliano Gresleri (Università degli Studi Bologna) wystąpił z tematem: Sztuka dla liturgii w myśli M.-A. Couturiera" (L'arte per la liturgia nel pensiero di M.-A. Couturier). Dominikanin M.-A. Couturier był artystą tworzącym w pierwszej połowie XX wieku († 1954).Zauważył on, że współczesny człowiek żyjący w środowisku miejskim potrzebuje takiego rodzaju sztuki, która koresponduje z jego środowiskiem życia. Tę myśl przewodnią M.-A. Couturiera podjął kard. G. Lercaro, który w 1955 roku zorganizował w Bolonii sympozjum Architektura sacra, kierując się mottem: „Wyśpiewać w języku żywych chwałę Boga żyjącego". Wyraziło się to w zaadoptowaniu sztuki modernistycznej w budowaniu nowych przestrzeni liturgicznych w zburzonych przez wojnę dzielnicach Bolonii.

W części popołudniowej wystąpiło kilku prelegentów z dużych miast Europy prezentujących doświadczenie w dziedzinie sztuki sakralnej. Pierwszym był Jonathan Goodall z Londynu, który przedstawił Sztukę liturgiczna w Kościele anglikańskim (L'arte liturgica nella Chiesa d'Inghilterra). Dzięki wielu emigrantom, którzy po II wojnie światowej osiedlili się na Wyspach Brytyjskich, widać rozwój sztuki sakralnej. W Kościele anglikańskim relacja między sztuką i liturgią jest uprzywilejowana, ponieważ tak jak liturgia przemienia osobę i jej ciało, tak sztuka ma przetworzyć przestrzeń i czas. Gesty, muzyka, elementy materialne wykorzystane podczas liturgii mają być formą przekazywania Dobrej Nowiny, inkarnacji, łaski przetwarzającej materię. Najważniejsi współcześni twórcy w tym Kościele to: S. Fyodorow, T. Denny, G. KilBride, F. Grier, S. Cox. 
Kolejnym prelegentem był Marco di Capua z Rzymu, który zaprezentował temat: Drzwi aniołów Igora Mitoraja (Le Porte degli angeli di Igor Mitoraj). Przedstawił on wejściowe drzwi bazyliki Santa Maria degli Angeli w Rzymie autorstwa Igora Mitoraja. Przypomniał, że Michał Anioł nie ukończył zleconej mu pracy, nie wykonał drzwi wejściowych do tego kościoła. Po kilku wiekach dokończenie dzieła zostało powierzone Mitorajowi, rzeźbiarzowi urodzonemu w Krakowie. Chciał on przez swoje dzieło przekazać ideę piękna. Jego drzwi są jakby łonem matki, symbolem wejścia do nowego świata. Jego dzieło zostało przez krytyka sztuki Marco di Capua ukazane jako właściwy przykład łączenia nowoczesności z klasyką (tradycją).

Następnie Guido Schlimbach z Ratyzbony przedstawił: Muzeum Kolumba w Kolonii (Il museo di Kolumba di Colonia). Muzeum to wybudowane na planie bazyliki zostało otwarte w 2007 roku. Znajdują się w nim różnego rodzaju eksponaty sztuki religijnej i liturgicznej pochodzące z różnych epok. Muzeum nie posiada wystawy stałej, ale co roku we wrześniu dokonuje się nowe usytuowanie zgromadzonych dzieł. Każda wystawa ma swoje motto, które określa ideę przewodnią zgromadzonej kolekcji.

Na koniec został zaprezentowany temat Nowy ewangeliarz Kościoła ambrozjańskiego (Il nuovo Evangeliario Ambrosiano). Prace nad nim jeszcze trwają. Będzie on podzielony na 3 tomy, każdy po 180 stron. Wypracowany został dla niego nowatorski charakter pisma. Każda perykopa ewangeliczna opatrzona zostanie odpowiednim obrazem. Obecnie trwają prace nad doborem artystów, którzy zagwarantują widzialność tekstu zapisanego w obrazie. Prelegentami byli: Pierluigi Cerri (grafika), Francesco Tedeschi (dobór artystów), Norberto Valli (teologia księgi) z Mediolanu.

Ostatni dzień sympozjum rozpoczął się od wystąpienia Christosa Yannarasa (Università Panteion Atene) zatytułowanego Sztuka jako manifestacja doświadczenia liturgicznego (L'arte come manifestazione dell'esperienza liturgica). Liturgia oznacza dzieło wspólne, więc to co indywidualne musi zniknąć. Wszystko ma być ofiarą miłości dla Boga - anaforą. Anafora jest skałą, każdy użyty materiał, kolor, muzyka w liturgii nie ma zadania dekoracyjnego. W Kościele Wschodnim celem obrazu nie jest prowokacja, emocje, ale wyrażenie wiary w Trójcę Świętą. Nie idziemy do kościoła, aby zdobywać cnoty, ale by poczuć, że śmierć jest zwyciężona. Dzieła niektórych artystów, nawet genialnych, jak np. Picassa, nie nadają się do użytku liturgicznego, bo nie potrafią przekazać prawdy o Bogu. Najważniejsza jest miłość, wszystko inne ma drugorzędne znaczenie.

Obrady podsumował P. De Clerk (Institut Catholique Paris). Zadał on pytanie, czy sztuka może czemuś służyć, czy nie straci w ten sposób swojej obiektywności, a także co zrobić, by poprawić jakość sztuki liturgicznej w dzisiejszym zsekularyzowanym świecie? Według niego nie jest możliwa sztuka tworzona przez kogoś, kto nie „czuje” Kościoła. Po reformie soborowej wytworzył się rodzaj rynku, na którym sztuka i liturgia walczą ze sobą. 